Physiotherapists' Perceptions of Their Role in the Rehabilitation Management of Individuals with

[6] Chipchase L, Dalton M, Williams M, Scutter S. ducation immune from evidence-based scrutiny? Aust J Physiother 2004:50(3):133-135.

Lekkas P, Larsen T, Kumar S, Grimmer K, Nyland L, Chipchase L, et al. No model of clinical education systematic review. Aust J Physiother 2007:53(1):19-28

8] Ferguson K, Edwards H. Providing clinical education: the relationship between healih and education. Health Professional Education. Ed: Higg L. Edward E. Oxford: Butterworth Heinemann 1999:52-60.

[9] Delany C, Bragge P. A study of physiotherapy Ded Teach 2009:31 (19):E402-E4

(10] Ernstzen DV, Bitzer E, Grimmer-Somers K. Physiotherapy students and Elinical teachers percepilions of elinical learning opportunities: a case study. Med

Smith M, Higgs J. (Eds) Trends in fieldwork education. Rotterdam L: Sense Publishers;2010.

[12] Escriba-Aguir V, Martin-Baena D, Perez-Hoyos S. Pychos Arch Occup Environ Health 2006:80:127-133.

Ahola K, Hakanen J. Job strain, burnout, and depressive symptoms: a prospective study among

[14] de Croon EM, Sluiter JK, Blonk RW, Broersen JP. Frings-Dresen MH. Stressful work, psychological job strain, and turnover: a 2-year prospective cohor
study of truck drivers. I Appl Psycho

[15] Head J, Kivimaki M. Martikainen P. Vahtera J, Ferrie $J E$, Marmot MG. Influence of change in psychosocial work characteristics on sickness absence: the 2006: 60 (1):55-61. J Epidemio

Krause N, Ragland DR, Fisher JM, Syme SL. Psychosocial job factors, physical workload, and incidence of work-elated spinal injury: a 5-year prospective study of Urban

17] Higashiguchi K, Morikawa Y, Miura K, Nishijo M, Tabata M, Yoshita K, et al. Review and Develop Inventory and its factors. Jpn J Hygiene Eker L. Tüzün EH (in Japanese). of job satisfaction among physiotherapist among Turkey. J Occup Heallh 2004,46(6).500-5.

and behavioral consequences of flexitime. Journa of applied psychology 1982;67(2):214-218.

[20] Pierce JL, Newstorm JW. The design of flexible work schedule and employee responses; Relation and process. Journat
1982:4:247-262.
[21] Rainey GW, Wolf L. Summer (1982) the organizationally dystunctional consequences of flexible work
hours: A general Overview. Public Personne management journal 1982; $11: 165-175$.
marsonne

[22] Bodur S. Job satisfaction of health care staff employed at health centers in Turkey. Occup Med (Lond) 2002:52(6): 353-355.23] Sur H, Hayran O, Mumcu $G$, soylemez $D$, Afli $H$ and Yildirim $C$. cross-sectional survey in Turkey. Eval health Prof 2004:27(2):152-164

[24] Whitfiel TWA, Allison I, Laing A, Turner PA. Percepthins of the physiotherapy profession: A compara-

[25] Blackmore ER, Stansfeld SA, Weller I, Munce Lagorski BM, Stewart DE. Major depressive episodes and work stess. resuls thom a national population Bourbonnais $R$, Vézina $M$, et al. Job strain and risk of acute recurrent coronary heart disease even

77] Williams ES, Manwell $1 B$, Kong. relationsh fion, and burnout with physician-reported error and suboptimal patient care. results from the MEMO 2007:32(3):203-212.

[28] Park JR, Coombs CR, Wilkinson AJ, Clarke JL, Arnold J, Preston D. Attractiveness of physiotherapy in the
National Health Service as a career choice: qualitaNational Healfh Service as a career choice. quallta

[29] Broom JP. Williams J. Occupational stress and nevelogical rehabilitation physiotherapists. Physiothera-

Py 1996:82 (11):606-614.
[30] Schuster ND, Nelson DL, Quisling C. Burnout among 11 Deckard GJ, Present RM. Impact of role stress on physical therapists' emotional and physical well-being. Phys Ther 1989;69(9):713-718.

Blau therapy in a changing health care environment. Phys Ther 2002;82(7):648-657.

[33] Grembowski D, Ultrich CM, Paschane D, Diehr ky physician satisfaction $\perp$ Am Board Fam Pract 2003:16(5):383-393.

[34] Bovier PA, Perneger TV. Predictors of work satisfac tion among physician

[35] Seo Y, Ko J, Price JL. The determinants of job salisfaction among hospital nurses: model estima tion in Korea. Int J Nurs Stud 2004;41 (4):437-446.

assistants and other no physician provish ician managed care setting. Public Health Rep 1995;110(6):714-719.

\section{ASSOCIATION OF PROLONG SITTING WITH COMMON MUSCULOSKELETAL DISORDERS AMONG PRIVATE AND PUBLIC SECTOR BANKERS}

\section{ABSTRAC}

o compare the frequency of common musculoskeletal disorders due to STUDY DESIGN

\section{STUDY SETTINGS \& PARTICIPANTS}

year were inducted in the study All bankers were divided into private one public sector groups. Employees were selected from private sector and public

DATA COLIECTION TOOL

sectors.

RESULTS

The study shows that $44.6 \%$ government employees were suffering from shoulder
pain, while $36.9 \%$ private sector bankers having this problem. Among then $18.2 \%$ of public sector bankers suffered from neck pain. However, only $9 \%$ of

CONCLUSION

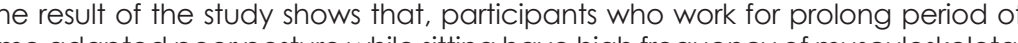
time adapted poor posture while sitting have high frequency of musculoskeletal about their health and posture as compared to the public sector bankers.

Mahmooda Naqvi Lauddin Univege of Physical Therapy mahmoodanaqvi@hotmail.com

Maryum Zehra

herapist Civil Hospital

Ghazala Noor Nizam

Ziauddin College of Physical Therapy

Ziauddin University

gazi_17@hotmail.com
[Naqvi M, Zehra M, Nizami GN. Association of prolong sitting with common musculoskeletal disorders among 
few bankers of both sectors had consulted to doctor.

\begin{tabular}{|c|c|c|}
\hline \multicolumn{3}{|c|}{ Table 3: Most Affected Region of WRMSDs } \\
\hline Region & $\begin{array}{c}\text { Private } \\
\text { Sector }\end{array}$ & $\begin{array}{c}\text { Government } \\
\text { Sector }\end{array}$ \\
\hline Shoulder & $17.0 \%$ & $24.1 \%$ \\
\hline Elbow & $4.0 \%$ & $0.4 \%$ \\
\hline Wrist & $3.1 \%$ & $4.5 \%$ \\
\hline Hip & $0.4 \%$ & $0.0 \%$ \\
\hline Knee & $3.1 \%$ & $5.8 \%$ \\
\hline Ankle & $1.3 \%$ & $0.0 \%$ \\
\hline Neck & $6.2 \%$ & $9.8 \%$ \\
\hline Back & $10.7 \%$ & $9.4 \%$ \\
\hline
\end{tabular}

According to these bankers, their common diagnoses
were adhesive capsulitis, cervical pains, lumber spondylo-

\begin{tabular}{|c|c|c|}
\hline \multicolumn{3}{|c|}{ Table 4: Working Postures } \\
\hline & PRIVATE & GOVERNMENT \\
\hline \multicolumn{3}{|l|}{ Posture } \\
\hline Forward & $16.2 \%$ & $26.2 \%$ \\
\hline Straight & $25.8 \%$ & $19.2 \%$ \\
\hline Lean & $8 \%$ & $4.5 \%$ \\
\hline \multicolumn{3}{|l|}{ Elbow at $90^{\circ}$} \\
\hline Yes & $30.5 \%$ & $29 \%$ \\
\hline No & $19.5 \%$ & $21 \%$ \\
\hline \multicolumn{3}{|c|}{ Wrist in neutral position } \\
\hline Yes & $31.5 \%$ & $27.5 \%$ \\
\hline No & $18.5 \%$ & $22.5 \%$ \\
\hline \multicolumn{3}{|l|}{ Knee at $90^{\circ}$} \\
\hline Yes & $30.5 \%$ & $31.5 \%$ \\
\hline No & $19.5 \%$ & $18.5 \%$ \\
\hline \multicolumn{3}{|c|}{ Monitor at eye level } \\
\hline Yes & $42 \%$ & $36.7 \%$ \\
\hline No & $8.3 \%$ & $13.1 \%$ \\
\hline \multicolumn{3}{|c|}{ Physical Activity } \\
\hline Gym activity & $9 \%$ & $7.5 \%$ \\
\hline Aerobics & $3.5 \%$ & $2.3 \%$ \\
\hline Walking & $14.3 \%$ & $28.1 \%$ \\
\hline None & $23.4 \%$ & $11.8 \%$ \\
\hline
\end{tabular}

As contrast to government sector, more private sector hours. While, forward bending is more common in government sector bankers $(26.2 \%)$. Percentages of working
postures of different body parts are described in Table
In response to question regarding their physical activity, in private sector bankers only $9 \%$ carry out gym activity and
$3.5 \%$ do cerobics. Walking is more common in govern$3.5 \%$ do aerobics. Walking is more common in govern-
ment sector bankers $(28.1 \%)$ as compare to private sector bankers (14.3\%). Remaining bankers of both sectors do not involve in any kind of physical activity, in which the percentage of private bankers is higher.

\section{DISCUSSION}

When the relationship between musculoskeletal symptoms and each individual were analyzed, hence,
the common factors were found to be associated with musculoskeletal symptoms are physical factors, specifically. These include intense, repeated, or sustained exertions and awkward, sustained or extreme postures of the body for prolong period of time with insufficient recovery time. Complaints often arise from the spine,
arms, hands and legs. Musculoskeletal symptoms are most often associated with computer jobs requiring constrained working positions for an entire work shift. In a sedentary position, the computer user is subjected to muscles. The amount of stress is dependent upostural the position of various parts of human body. Holding the head to the side or forward may lead to neck and shoulder fatigue and pain ${ }^{17}$. Other neck and shoulder
complaints result from the use or position of the operators arms For example, elevation of the arms will add strain to neck and shoulder. Prolonged and constrained postures that are required by the job will worsen this condition. In the long-earm, this cont juous wer and tear may result in

Researches indicated that musculoskeletal symptoms are more frequently reported by computer operators than
workers in traditional jobs. Epidemiologic studies of workers have associated with several disorders in many Exposure to these known factors increases the incidence of WRMSDs among bankers. Our study illustrates the
effects of ergonomics on problems of musculoskeletal system, focusing on office ergonomics, posture adijustable chair, working hours, intervals, physical activity and prolong sitting. The authors of reviewed various studies hat physical and psychosocial factors of the individual can contribute to the development and persistence of
musculoskeletal symptoms ed to compare the frequency of MSDs among private and public sector bankers, as they are more prone to WRMSDs due to prolong sitting on computers. Our study complaining musculosk sector bankers (49.5\%). Similar study by Bernard BP
secting showed that, job requiring the use of computers input workers to awkward, sustain postures and repetitive motions of the upper extremities, which demonstrate as the cause of work related shoulder and neck pain'2 Another study by Korhonen et al found that, an incident

Similarly, we noticed that bankers using computers and back shows highest percentages of shoulder, neck and back complaints. A similar study by Hernandez et al and hand WRMSDs in 179 newspapers workers using VDTS. compared with non-VDT users in the same company23. A sidy concluded that musculoskeletal symptoms of Visual Display Unit (VDU) users are believed to have a neck posture, work station design and duration of work as well psychological, social factors such as time pressure and high perceived work load ${ }^{124227}$. The US Occupationa safety and Health Administration (OSHA) and VDT guidelines allow companies to determine the presence
of WRMSDs risk factor and provide specific recommendations for safe seating and VDT setups in order to protect the office workers28. Cook and Kothiya demonstrated that, the position of mouse closer to the
keyboard and eliminating the numeric keypad, resulted in significantly lower deltoid muscle electromyography activity in VDT users, than when the mouse was placed in a position where the user was required to abduct the
upper extremity and reach for the mouse? upper extremity and reach for the mouse 29 . Authors of
different studies concluded that, computer use might be
more strongly related to the disorders of hand and arm than the disorders of shoulder and neck ${ }^{30}$. Hence, our study also shows similar results that, $63 \%$ of private sector using keyboard and among them only $6.7 \%$ shows wile saing

Results of our study shows that, $52.5 \%$ of public sector bankers are working in forward bending posture; whil
only $32.5 \%$ of private sector bankers are working in forward bending positions, which were causing shoulde and neck pain in bankers. A similar study proposed that prolong sitting at work for more than $95 \%$ of the working neck pain ${ }^{31}$. Our study shows that, $45.2 \%$ of governmen sector bankers feel discomfort affer $1 / 2$ an hour of working in static posture as compare to the private sector banker discomfort after an hour of continuous working in $1 \%$ ) fee posture than private sector bankers (22.5\%). P-value of ess than 0.05 shows significant results. It also shows strong association of discomfort with prolong sitting posture L demonstrated that, lack of spinal motion seems to be isk factor among low back pain patients. $85 \%$ of patient have backache due to prolong sitting, $73 \%$ due to
prolong standing, only $23 \%$ by walking and $15 \%$ by prolong stanc
cycling ${ }^{32}$.

Another study shows that, workstation design and faulty postures in sitting for extended periods, lead to poor circulation, stiffness of joints and pain. In compute
handling, we should consider span of usage, duration otal work, number of consecutive hours, nature of job. type of computer used and its placement ${ }^{33}$.

According to Community Workers of America Occupa-

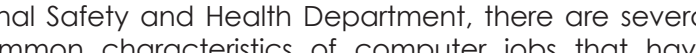
been related to increased musculoskeletal complaints. These include the design of the computer and workste fion equipment, work pace, repelinveness of the job: the workers ${ }^{34}$. All of these factors must be addressed to educe postural complaints effectively. Office ergonom ics training is beneficlal for exhibiting significant increas in knowledge about body postures; ergonomics design The current literature also demonstrates that, we can working station. This study aims to compare the effects of an office ergonomics on self-reported musculoskeleta discomfort, group performance and business performance efficacy among private and public sector MSDs $\$ 15$ billion to $\$ 20$ billion per year. Our study shows health and posture as compared to the public sector.

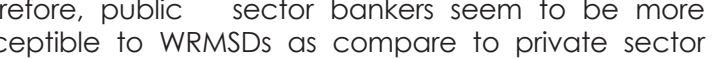
susceptib

\section{CONCLUSION}

his study shows evidence of strong association between WRMSDs, prolong siling and poor workstation among helpful for future research, assessing the prognosise musculoskeletal disorders among bankers. This study encourages the bankers to consider the savings that they would make raber than looking at the costs only while reduce MSDs.

\section{REFERENCE}

1] JuUlkristensen B, Jensen C. Self-reported workplace for musculoskeletal symptoms: the "BIT" follow wp study on office workers. Occup environ Med 2005;62(3):188-94

Jensen C, Finsen L, Sgaard K, Christensen $\mathrm{H}$. Computer and mouse use. Int I Ind Ergon 2002;30(4-5):265-75.

[3] Genaidy AM, Karwowski W. The effects of neutral posture devitions on perceived joint discomfort 1993:36(7):758-92. (4) Jensen C. Development of neck and hand-wrist symptoms in relation to duration of computer use at
work. Scand J Work Environ Health

Roney T, Podger G, Hackitt J. The Role of the Health and Safety Commission and the Health and Safety. Third report of session 2007-08. Volume II. Available ment.uk/pa/cm200708/cmselect/cmworpen/cmworpen.htm.

[6] Lost-work time injuries and illnesses: Characteristics and resulting days away from work, 2003. News, Statistics, Washington. D.C. 20212.2005. March 30. Available from: http://www.bls.gov/news.re-

lease/archives/osh2_003302005. pdf
Aaras A, Hogen G, Biorset HH, Ro O, Thoresen M. Aaras $A$, Hogen $G$, Bjorset $\mathrm{HH}, \mathrm{RO} O$, Thoresen $\mathrm{M}$.
Musculoskeletal, visual and psychosocial stress in
VDU

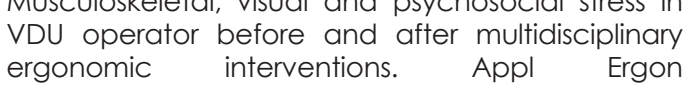
1998:39:335-5

[8] Andersen JH, Kaergaard A, Mikkelsen S. Risk factors study of workers in industrial and senice companies. Occup Environ Med 2003;60:649-54 David GC. Ergonomic methods for assessing exposure to risk factors for work-related musculo-
skeletal disorders. Occup Med 2005:55:190-199

10] Wahlistorm J. Ergonomics, musculoskeletal disorder and computer work. Occup Med 2005:55(3): $168-76$. spurgeon. The prevention of musculoskeletal disorders within the telecommunications sectors: a systemic review $2008 ; 3(1): 56-72$.

12] Punnett L, Gold J, Katz JN, Gore R, Wegman DH. Ergonomic stressors and upper extremity musculo-
skeletal disorders in automobile manufacturing One year follow up study. Occup Environ Med 2004:61 (8)::668-74.

of ergorest arm supports on muscle strain and wist 
positions during the use of the mouse and keyboard in work with visual display units: a work
tion. Int J Ind Ergon 2001; $7(1): 103-1$.

[14] Michael J, O'Neill. Work space adjustability, storage, and Performance

15] Marcus M, Gerr F, Monteilh C, Ortiz DJ, Gentry E. Cohen $\mathrm{S}$ et al. A prospective study of computer symptoms and disorders. Am a IndMed 2002:41 (4):236-49.

[16] Safety and Health Assessment and Research for Prevention Safety \& Health Assessment and Industries. Washington D C. 1993 . Available from http://en.wikipedia.org/wiki/Occupational_safety_and_health

[17] Dul J, Weerdmeester B. Ergonomics for beginners. Corlettl E N. Manenica. The Effects

ments of Working Posture. Appl Ergo 1980:1 1(1:1:-16 Ketola R, Toivonen R, Hakkanen M. Effects of ergonomic intervention in work with video display

[20] Kogi K, Kawakami Tani JMBatino Low-cost work improvements that can reduce the risk of musculoskeletal disorders. Int J Ind Ergon 2003;31 (3):179-84.

Workplace Factors: A Critical Review of Episemio Wgic Evidence for Work-Related Musculoskeleta Disorders of the Neck, Upper Extremity, and Low Back. CDC.1997. DHAS (NOSH) Publication No. docs/97-141/pdfs/97-141.pdf

22] Korhonen I, Ketola R, Toivonen. Work-related and nalividual predictors for incident neck pain among office employees working with video display units.

23] Hernandez LO, Gonzalez ST, Alcantara SM, Ramirez IM. Computer use increases the risk of musculoskele-
tal disorders among newspaper office workers. Arch
Med Res 2003;34:331-342.

Bongers PM, de Winter CR, Kompier MA et al

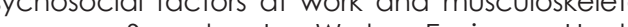

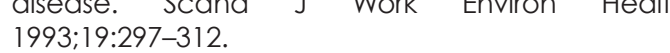

[25] Faucett J, Rempel D. VDT-related musculoskeleta symptoms: interactions between work posture and
psychosocial work factors. Am J Ind Med psychosocial work

[26] Tittiranonda $P$. Burastero $S$, Rempel D. Pisk factors for musculoskeletal disorders among computer users. Occup Med 1999:14:17-38.

[27] Nakazawa T, Okubo Y, Suwazono Y, et al. Associative symptoms Am J Ind Med 2002:42:421-26.

[28] Computer Workstation Tool. Occupational Safe and Health Administration. December 2008; Availa ble at Available from: hitp.//Www.osha.gov-

[29] Cook CJ Kothiyd K. Influence of mouse position on muscular activity in the neck, shoulder, and arm in computer users. Appl Ergon 1998;29:439-443.

shoulder and wrist-hand symptoms in for neck follow up study of 3,990 employees in Denmark. Arch Occup Environ Health 2002; $75: 243-5$.

[31] Jmker Sl, Huysmans MA, Blatter BM, vander Beek workers spend few hours on their could office Occup Environ Med 2007:64(4):211-222

[32] Van Deursen LL, Patijn J, Durinck JR, Brouwer R, va Erven Sommers JR, Vortman BJ. Sitting and low back 1999:8(3): $187-93$.

[33] Bammer G, Martin B. The arguments about RSI: an examination. Community Health Study

al Safety and Health manual washington DC; 2000; Available at: www.cwaunion.org/issues/entry/c/health-and-safety

\section{FREQUENCY OF WORK RELATED LOW BACK PAIN AMONG PHYSICAL THERAPISTS}

\section{ABSTRAC}

the frequency of work, related to Low Back Pain (LBP) among physical therapist of tertiary care hospital of Karachi. To analyze the effects of Related Low Back Pain (WRLBP) as well.

\section{STUDY DESIGN AND SAMPLING TECHNIQUE}

was conducted with non-probability convenience sampling technique was used.

STUDY SETTINGS \& PAPTICIPANTS

Karachi.

\section{DATA COLLECTING TOOL AND DATA ANALYSIS}

RESUIT

This study reported that prevalence of WRLBP was $66.4 \%$. The rate was higher in
femalephysiotherapist, that is, 42.6\%. Data revealed that. $69 \%$ of respondents experienced WRLBP within 2 years of their practices. Moreover, the manual therapy was found to be the most common cause for WRLBP. No significan assocapist but interestingly, it was found that sub-specialty area of work was correlated with WRLBP.

CONCLUSION

列 strengthen training for prevention at undergraduate level in order to strategy, strengthen training for
and prevent WRLBP.
Saima Javed sam4javraj@gmail.com Anum Jawaid Sultan anumjawaidsultan@gmail.com

Dr. M. Usman Khan

Ziauddin College of Physical Therapy m_khanusman@hotmail.com

Maria Rahim

Ziauddin College of Physical Therapy rhm.maria@gmail.com 